\title{
Thermodynamically designed target-specific DNA probe as an electrochemical hybridization biosensor
}

\author{
Faruk Can $^{\mathrm{a}}$, Hatice Eser Ökten ${ }^{\mathrm{b}}$, Tülay Ergön-Can ${ }^{\mathrm{c}}$, Pınar Ergenekon ${ }^{\mathrm{a}}$, Melek Özkan ${ }^{\mathrm{a}}$, Elif Erhan ${ }^{\mathrm{d}, *}$ \\ ${ }^{a}$ Gebze Technical University, Department of Environmental Engineering, 41400 Gebze, Kocaeli, Turkey \\ ${ }^{\mathrm{b}}$ Izmir Institute of Technology, Department of Environmental Engineering, 35430 Urla, Izmir, Turkey \\ ' Atatürk University, Department of Biology, Faculty of Science, 25240 Erzurum, Turkey \\ ${ }^{\mathrm{d}}$ Uskudar University, Department of Bioengineering, 34662 Uskudar, Istanbul, Turkey
}

\section{A R T I C L E I N F O}

\section{Article history:}

Received 30 December 2019

Received in revised form 7 May 2020

Accepted 8 May 2020

Available online 15 May 2020

\section{Keywords:}

Electrochemical

DNA biosensors

Environmental monitoring

Hybridization

Oligonucleotide probe design

\begin{abstract}
A B S T R A C T
Applications of molecular techniques to elucidate identity or function using biomarkers still remain highly empirical and biosensors are no exception. In the present study, target-specific oligonucleotide probes for $E$. coli $\mathrm{K} 12$ were designed thermodynamically and applied in an electrochemical DNA biosensor setup. Biosensor was prepared by immobilization of a stem-loop structured probe, modified with a thiol functional group at its $5^{\prime}$ end and a biotin molecule at its $3^{\prime}$ end, on a gold electrode through selfassembly. Mercaptopropionic acid (MPA) was used to optimize the surface probe density of the electrode. Hybridization between the immobilized probe and the target DNA was detected via the electrochemical response of streptavidin-horseradish peroxidase in the presence of the substrate. The amperometric response showed a linear relationship with the target DNA concentration, ranging from 10 and $400 \mathrm{nM}$, with a correlation coefficient of 0.989 . High selectivity and good repeatability of the biosensor showed that the thermodynamic approach to oligonucleotide probe design can be used in development of electrochemical DNA biosensors.
\end{abstract}

(c) 2020 Published by Elsevier B.V.

\section{Introduction}

DNA biosensors are becoming increasingly important and practical tools in pathogen detection, molecular diagnostics, food safety control, and environmental monitoring [1]. A variety of DNA biosensors based on different detection strategies have been developed over the past 20 years, including optical [2,3], magnetic [4], piezoelectric [5-7], and electrochemical methods [8-12]. Among them, the electrochemical biosensors attracted considerable attention for their intrinsic advantages, such as easy to use, rapid response, high sensitivity, good selectivity, low cost and need for inexpensive instrumentation [13].

Since the discovery of the electroactivity of DNA bases [14], various strategies have been investigated for the improvement of the sensitivity and selectivity of electrochemical DNA detection. Unfortunately, there is usually a trade-off between specificity and sensitivity. The following three criteria play an important role in the design of DNA sensors for the determination of overall biosensor performance: (i) selection of a suitable analytical technique, (ii) an immobilization method for the probe on the electrode surface,

\footnotetext{
* Corresponding author.

E-mail address: elif.erhan@uskudar.edu.tr (E. Erhan).
}

and (iii) establishment of a target-specific probe [15]. The capture probe has the most important role in the selectivity of biosensor. However, when molecular techniques using genetic markers such as DNA and RNA were investigated, several problems were observed in terms of the comparability and reproducibility of results [16]. Inconsistent results in terms of sensitivity and selectivity were mainly due to use of melting point $\left(T_{m}\right)$ approach in probe design and varying experimental conditions such as denaturant concentration [17]. The highly empirical $T_{m}$ approach has been used conventionally in the design of the oligonucleotide probes. However, this approach suffers from various theoretical deficiencies. Firstly, it does not give any specific information about the value of hybridization temperature except pointing out that it shall be below the calculated $T_{m}$. It ignores the sequence of the nucleotide bases and thus nearest neighbor interactions, which govern the likelihood of a stable hybrid formation thermodynamically. $T_{m}$ is not a precise indicator of whether hybridization of the DNA probe with target DNA will occur. Furthermore, it may cause false negative or false positive results since nearest-neighbor thermodynamic interactions are completely overlooked $[18,19]$. Success of this method is predominantly based on empirical results which limits the validity, sensitivity and specificity. Yilmaz and coworkers employed thermodynamic laws in calculating the hybridization 
energy of the target/probe hybrid for a model microorganism in fluorescent in situ hybridization (FISH) experiments, and they determined an energy range in which the hybridization signal was acquired with sufficient selectivity $[20,21]$. Thus, they developed a mechanistic approach to a thus far empirical problem and standardized the experimental method. When the electrochemical DNA biosensor studies in literature were reviewed within the scope of this approach, it was observed that previously used probes had very high thermodynamic affinities which might facilitate unspecific hybridization. Hence the probe might hybridize with a mismatch target DNA and produce a false positive signal. This problem increases the possibility of error in determination of species in a mixed culture environment and reduces the reliability of results. However, probes designed using a thermodynamic approach may provide more specific target affinity resulting in high selectivity and sufficient signal intensity.

This study is based on the idea of using the most functional sequence of the oligonucleotide probes which can be designed in various configurations, and obtaining a stable hybridization of the probe with its target DNA. The application of the thermodynamic approach in the design of electrochemical DNA biosensors is expected to be a convenient solution in terms of repeatability and selectivity of the results. For this purpose, a target-specific biotin-labelled oligonucleotide probe to $E$. coli K12 was designed thermodynamically and applied in an electrochemical DNA biosensor. Streptavidin-horseradish peroxidase conjugate (St-HRP) was used in the electrochemical signal amplification.

\section{Experimental}

\subsection{Materials and instrumentation}

Oligonucleotide sequences for both probes and targets are listed in Table 1. Target sequence (T1) was selected from the intergenic spacer region of $E$. coli $\mathrm{K} 12$ strain (GenBank accession number U00096.3, nucleotide numbering 360 to $440,5^{\prime}$ to $3^{\prime}$ ) in order to differentiate from 0157:H7 strain. Underlined sequence of T1 target DNA shows perfect complementary region to $\mathrm{P} 1$ and $\mathrm{P} 2$ probes (Table 1). $\mathrm{T} 1$ * was designed to have a single-base mismatch in the middle of the hybrid. Besides, the experiments were carried out with P3 probe, which was identical to an oligonucleotide probe used in a previous study [22], in order to compare the experimental results. P3 probe was not targeting any specific region. T3 was the perfect complementary to a segment on P3 (as underlined in Table 1) while T3* had a single-base mismatch. A complete mismatch probe (Random), that would not bind to target sequence, was also synthesized in order to conduct optimization studies on electrode surface coverage. Oligonucleotide probes were functionalized with a thiol group (-SH) at the $5^{\prime}$ end and with a biotin group at the $3^{\prime}$ end. Unmodified oligonucleotides were purchased from Iontek Inc., (Istanbul, Turkey) and modified oligonucleotides were purchased from Avetra Bioscience Llc., (California, USA). All probes were used without further purification.

In order to test sensitivity and selectivity, probes were designed by adopting the thermodynamic approach previously developed by Yilmaz and Noguera (2004) [20]. The overall standard Gibbs free energy changes $(\Delta G)$ were calculated using the following equation (Eq. 1).

$\Delta G_{\text {overall }}^{0}=-R T \ln \left[\frac{e^{-\Delta G_{1}^{0} / R T}}{\left(1+e^{-\Delta G_{2}^{0} / R T}\right)\left(1+e^{-\Delta G_{3}^{0} / R T}\right)}\right]$

where $\mathrm{R}$ is the gas constant $\left(1.987 \mathrm{cal} \mathrm{mol}^{-1} \mathrm{~K}^{-1}\right)$ and $\mathrm{T}$ is the hybridization temperature $\left({ }^{\circ} \mathrm{K}\right) . \Delta \mathrm{G}_{1}^{0}, \Delta \mathrm{G}_{2}^{0}$ and $\Delta \mathrm{G}_{3}^{0}$ were the free energy changes of the reactions for binding of the probe to the available complementary DNA, folding/unfolding of the probe and folding/unfolding of the target DNA, respectively [23]. $\Delta G_{1}^{0}$ was predicted from the nearest-neighbor thermodynamic model (Table S1). $\Delta G_{2}^{0}$ and $\Delta G_{3}^{0}$ were analyzed by using mfold software [24]. The calculated $\Delta \mathrm{G}$ values for P1, P2 and P3 probes are presented in Table 2.

Later, Okten and coworkers reported the validity of thermodynamic approach for several organisms and it was shown that setting an overall Gibbs free energy range for formed hybrid in probe design $\left(-13 \mathrm{kcal} \mathrm{mol}^{-1}\right.$ to $-15 \mathrm{kcal} \mathrm{mol}^{-1}$ ) enabled overcoming sensitivity and selectivity issues [25]. If a probe has a low affinity (hybrid having an overall free energy higher than $-13 \mathrm{kcal} \mathrm{mol}^{-1}$ ), then hybridization might not occur. On the contrary, if the probe has a high affinity (hybrid having an overall free energy lower than $-15 \mathrm{kcal} \mathrm{mol}^{-1}$ ), then unspecific bindings might easily occur especially for one nucleotide mismatch cases. P1 was designed as a perfect complementary to T1 target sequence. However, our aim was to achieve the highest selectivity without signal loss. P2 probe was designed to stay in the predetermined free energy range and to keep the perfect molecular beacon structure. In order to achieve that, the first nucleotide on $5^{\prime}$ end of P1 was omitted and two nucleotides were added to $3^{\prime}$ end. Furthermore, the length of the spacer at $5^{\prime}$ end reduced from $\mathrm{C} 6$ to $\mathrm{C} 3$. The P2 configuration also circumvented any possible conflicts between the spatial structure of $\mathrm{P} 1$ probe and the enzyme labeling method based on biotin-streptavidin specific interaction.

Albumin bovine serum (BSA), hydroquinone (HQ) and streptavidin labeled horseradish peroxidase (St-HRP, Catalog No. S2438) were products of Sigma. 3-Mercaptopropionic acid (MPA) and hydrogen peroxide $\left(\mathrm{H}_{2} \mathrm{O}_{2}\right)$ were purchased from Merck. All reagents were of analytical grade and were used as received.

Cyclic voltammetry (CV) was carried out on a gold electrode (electrode surface area: $0.0314 \mathrm{~cm}^{2}$ ) using a CHI 842B Electro-

Table 1

Oligonucleotides used in the experiments.

\begin{tabular}{|c|c|c|c|c|}
\hline Oligonucleotide & Description & Sequence $\left(5^{\prime} \rightarrow 3^{\prime}\right)$ & $\begin{array}{l}5^{\prime} \\
\text { modification }\end{array}$ & $\begin{array}{l}3^{\prime} \\
\text { modification }\end{array}$ \\
\hline P1 & $\begin{array}{l}\text { Perfect complementary to underlined region of T1 (E. coli } \\
\text { K12) }\end{array}$ & CACGAACAACTTTCATTGTTC & $-\mathrm{SH}(\mathrm{C} 6)$ & Biotin-dT \\
\hline P2 & $\begin{array}{l}\text { The first nucleotide on } 5^{\prime} \text { end of P1 was omitted and two } \\
\text { nucleotides were added to } 3^{\prime} \text { end }\end{array}$ & ACGAACAACTTTCATTGTTCGT & $-\mathrm{SH}(\mathrm{C} 3)$ & Biotin-dT \\
\hline P3 & Probe used by Mao et al. (2008), no specific target & ACACGCTCATCAAGCTTTAACTCATAGTGAGCGTGT & $-\mathrm{SH}(\mathrm{C} 6)$ & Biotin-dT \\
\hline $\mathrm{T} 1$ & E. coli $\mathrm{K} 12$ intergenic spacer region & $\begin{array}{l}\text { TGAAACACTGAACAATGAAAGTTGTTCGTGAGTCTCTCAA } \\
\text { ATTTTCGCAACACGATGATGGATCGCAAGAAACATCTTCG }\end{array}$ & - & - \\
\hline $\mathrm{T} 1^{*}$ & Single-base mismatch to $\mathrm{P} 1$ and $\mathrm{P} 2$ probes & GAACAATGACAGTTGTTCGTG & - & - \\
\hline T3 & Perfect complementary to underlined region of $\mathrm{P} 3$ probe & ACGCTCACTATGAGTTAAAGCTTG & - & - \\
\hline T3* & Single-base mismatch to $\mathrm{P} 3$ probe & ACGCTGACTATGAGTTAAAGCTTG & - & - \\
\hline Random & Complete mismatch to $\mathrm{P} 1, \mathrm{P} 2$, and $\mathrm{P} 3$ probes & CGCGTATTCTTCATTCGGAACA & - & - \\
\hline
\end{tabular}


Table 2

Gibbs free energy values and structures of designed probes.

\begin{tabular}{|c|c|c|c|c|c|c|}
\hline Name & Sequence $\left(5^{\prime} \rightarrow 3^{\prime}\right)$ & $\Delta \mathrm{G}_{1}^{0} \mathrm{kcal} \mathrm{mol}^{-1}$ & $\Delta \mathrm{G}_{2}^{0} \mathrm{kcal} \mathrm{mol}^{-1}$ & $\Delta \mathrm{G}_{3}^{0} \mathrm{kcal} \mathrm{mol}^{-1}$ & $\Delta \mathrm{G}_{\text {overall }}^{0} \mathrm{kcal} \mathrm{mol}^{-1}$ & Structure \\
\hline P1 & CACGAACAACTTTCATTGTTC & -24.1 & -3.13 & -3.13 & -17.8 & 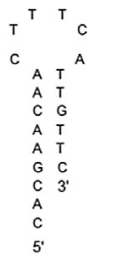 \\
\hline P2 & $x^{2}$ & -22.6 & -6.35 & $-3,13$ & -13.1 & 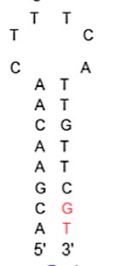 \\
\hline P3 & ACACGCTCATCAAGCTTTAACTCATAGTGAGCGTGT & -28.6 & -8.22 & -1.55 & -18.8 & 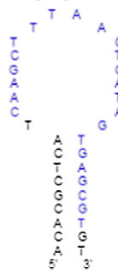 \\
\hline
\end{tabular}

chemical Workstation (CHI Instruments Inc., USA). A threeelectrode configuration consisting of a modified gold-disk working electrode, an $\mathrm{Ag} / \mathrm{AgCl}$ as the reference electrode, and a platinum wire auxiliary electrode was used.

\subsection{Preparation of DNA-modified gold electrode}

The gold electrode was mechanically polished with $1,0.3$ and $0.05 \mu \mathrm{m} \mathrm{Al}_{2} \mathrm{O}_{3}$ slurry and it washed ultrasonically in distilled water and ethanol for $5 \mathrm{~min}$, respectively. After mechanical cleaning, gold electrode was chemically treated by immersion in piranha solution $\left(\mathrm{H}_{2} \mathrm{O}_{2} / \mathrm{H}_{2} \mathrm{SO}_{4}, 1: 3 \mathrm{v} / \mathrm{v}\right)$ for $10 \mathrm{~min}$ at room temperature. Subsequently, it was electrochemically cleaned in $1 \mathrm{M} \mathrm{H}_{2} \mathrm{SO}_{4}$ while conducting potential scanning between -0.3 and $1.5 \mathrm{~V}$ until a reproducible cyclic voltammogram was obtained. Then it was rinsed with distilled water and, finally blown dry with highpurity nitrogen prior to monolayer adsorption. The cleaned gold electrode was immersed in mixture of $1 \mu \mathrm{M}$ thiolated stem-loop DNA and $5 \mu \mathrm{M}$ MPA solution in $0.1 \mathrm{M}$ phosphate buffer solution (PBS) at pH 7.4 including $1 \mathrm{M} \mathrm{NaCl}$ and was incubated overnight at $4{ }^{\circ} \mathrm{C}$. Then the modified electrode was thoroughly rinsed with $0.1 \mathrm{M}$ PBS and purified water to remove the weakly adsorbed stem-loop DNA. Stem-loop structured oligonucleotide should be treated subsequently at $75{ }^{\circ} \mathrm{C}$ and ice-cold bath for 30 and $10 \mathrm{~min}$, respectively in order to avoid the forming of duplex between two single-stranded DNA sequences.

\subsection{Hybridization and amperometric analysis}

The PBS (0.1 M, pH 7.4) including $1 \mathrm{M} \mathrm{NaCl}$ was used as the hybridization buffer. DNA hybridization was initialized by pipetting $20 \mu \mathrm{l}$ of target DNA onto the stem-loop DNA modified gold electrode and proceeding for $2 \mathrm{~h}$ at $37^{\circ} \mathrm{C}$. A piece of wet cotton was placed in hybridization chamber to avoid drying. Then the electrode surface was washed with water to remove unbound target oligonucleotides.

The resulting electrode was then soaked in an Eppendorf tube containing $1 \%$ BSA for $1 \mathrm{~h}$ to block active sites of the electrode. After rinsing with PBS, $20 \mu \mathrm{l}$ of streptavidin-HRP $\left(10 \mu \mathrm{g} \mathrm{ml}^{-1}\right)$ was pipetted on the surface of electrodes and was incubated at $4{ }^{\circ} \mathrm{C}$ for $30 \mathrm{~min}$. After being rinsed with PBS, the electrodes were soaked in $0.1 \mathrm{M}$ PBS ( $\mathrm{pH} 7.4)$ and were stored at $4{ }^{\circ} \mathrm{C}$ prior to measurement.

Electrochemical quantification was performed amperometrically in $10 \mathrm{ml}$ of $0.1 \mathrm{M} \mathrm{PBS}$ ( $\mathrm{pH} 7.4$ ) containing $1 \mathrm{mM}$ hydroquinone at a working potential of $-0.15 \mathrm{~V}$ (vs. $\mathrm{Ag} / \mathrm{AgCl}$ ), under unceasing stirring. When transient currents reached to a steady-state value, $10 \mu \mathrm{l}$ of $3 \% \mathrm{H}_{2} \mathrm{O}_{2}$ (2 mM final concentration) was added to the solution. A sharp increase in reduction current implied that streptavidin-HRP was captured on the electrode.

Assay was performed using stem-loop probes (or molecular beacons) modified with functional groups that while one end of the probe enabled immobilization on electrode surface, the other allowed enzyme binding. The working principle of the assay was based on measurement of enzymatic activity after unfolding of stem-loop probe following the hybridization reaction [22,26-29]. As shown in Schematic 1, highly stable monolayers were acquired through specific bonding between thiol (-SH) groups at $5^{\prime}$ end of the probe and the gold surface. Biotin on the other end of the probe was in closed configuration initially and it was not able to bind with streptavidin as a result of probe design. However, as hybridization reaction proceeded, the stem-loop structure of probe unfolded to allow target binding and therefore biotin molecule became free to react with streptavidin-HRP, away from the electrode surface. As a result, streptavidin-HRP conjugate could easily bind to biotin molecule at the $3^{\prime}$ end of the probe in order to catalyze the hydroquinone-mediated $\mathrm{H}_{2} \mathrm{O}_{2}$ reduction, which produced an amplified electrochemical signal. The acquired enzymatic signal meant that hybridization was successful.

\section{Results and discussion}

\subsection{Optimization of surface density of the probe}

Overall performance of electrochemical DNA biosensors strongly depends on surface chemistry of the layer used as an interface between DNA probe and electrode transducer. In particu- 
Streptavidin-Horseradish peroxidase conjugate

(B) Biotin

Electron transfer

$\mathrm{HQ}$ : Hydroquinone

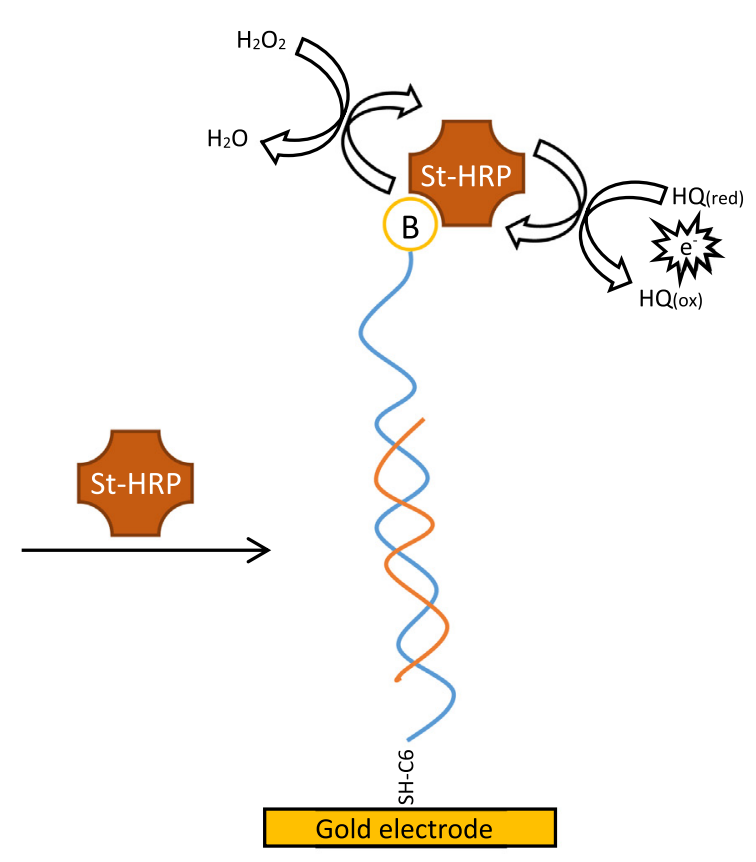

Gold electrode

Schematic 1. Illustration of a stem-loop structured DNA probe for enzymatic detection of target sequence.

lar, control of the surface chemistry and coverage of electrode substrate are essential for maximizing hybridization efficiency and minimizing non-specific adsorption incidents. Therefore, capture probe, P2, was diluted with MPA in order to obtain sufficient electrode surface coverage so that not only a detectable signal was produced but also enough space was provided for target molecule to reach its complementary probe, facilitating hybridization reaction. Probe:MPA ratios of $1: 1,1: 5$ and $1: 10$ were set to prepare electrodes which were then used for hybridization with their targets at $37^{\circ} \mathrm{C}$ for $2 \mathrm{~h}$. Fig. 1 shows the amperometric response of biosensors to the addition of $\mathrm{H}_{2} \mathrm{O}_{2}(2 \mathrm{mM})$ in $0.1 \mathrm{M}$ PBS at the potential of $-0.15 \mathrm{~V}$ (vs. $\mathrm{Ag} / \mathrm{AgCl}$ ), with different surface densities for random, single-base mismatch $\left(\mathrm{T} 1^{*}\right)$ and perfect match (T1) target probes, respectively. At the ratio of $1: 10$, probe density on the surface was minor, hence a decrease in signal and selectivity of biosensor was observed. Despite the fact that signal increased at the ratio of $1: 1$, at which electrode surface was exposed to highest concentration of probe, selectivity decreased. At 1:1 ratio, the electrochemical signals acquired from biosensor hardly differentiated between complementary and mismatch targets. We believe that it was caused by a decrease in signal-to-noise ratio as could be observed from random target response when most of the electrode surface was covered with probe that by itself produced an electrochemical signal. At the ratio of 1:5, biosensor response was within adequate range and difference of signal between complementary and single-base mismatch targets was significant. Therefore, all the subsequent experiments were performed using MPA to probe ratio of $1: 5$.

From the data in Fig. 1, it was apparent that there were three important roles of MPA, which provided a hydrophilic surface via carboxylic functional group. Firstly, through providing a gap between the oligonucleotides it created available space for hybridization. Secondly, it prevented non-covalent bonding between DNA backbone and gold electrode, especially for nitrogen containing nucleotide bases. Hence probe maintained the original structure, and also biotin was kept at desired positioning. Third, the presence of MPA also prevented the adsorption of streptavidin-HRP to the electrode surface directly through hydrophobic and electrostatic interactions.

\subsection{Effect of probe immobilization time}

Immobilization of DNA probe to gold electrode was done via gold-thiol (Au-SH) chemistry. In this method, a self-assembled monomolecular layer was formed between thiol ( $\mathrm{SH}$ ) groups and gold $(\mathrm{Au})$ surface. In order to achieve stable coating on the surface, immobilization time was investigated by monitoring electrochemical behaviour in the presence of ferricyanide. While electron transfer between bare electrode surface and ferricyanide ion was maximum, it decreased gradually as the electrode surface was coated with probe and MPA. Fig. 2a shows the square-wave voltammograms (SWVs) with an amplitude of $25 \mathrm{mV}$ and a frequency of $15 \mathrm{~Hz}$ for different incubation periods in the media containing $5 \mathrm{mM}$ ferricyanide and $0.1 \mathrm{M} \mathrm{KCl}$ after being incubated in P1:MPA $(1: 5 \mu \mathrm{M})$ mixture solution at $4{ }^{\circ} \mathrm{C}$. As shown in Fig. $2 \mathrm{~b}$, current change reached steady state after $10 \mathrm{~h}$ of incubation. Therefore, at least $10 \mathrm{~h}$ of probe immobilization was done for the rest of the experiments.

\subsection{Hybridization time}

Fig. 3 shows the amperometric response of the biosensors to the addition of $2 \mathrm{mM} \mathrm{H}_{2} \mathrm{O}_{2}$ in $10 \mathrm{ml}$ of $\mathrm{PBS}(0.1 \mathrm{M}, \mathrm{pH} 7.4)$ at the potential of $-0.15 \mathrm{~V}$ (vs. $\mathrm{Ag} / \mathrm{AgCl}$ ) after prepared biosensors (P1) were incubated at $37{ }^{\circ} \mathrm{C}$ with $1 \mu \mathrm{M}$ target sequences (T1) to evaluate the effect of the hybridization time as $2,4,6$, and $24 \mathrm{~h}$, respectively. The amperometric results were similar for the hybridization time of 2, 4, or $6 \mathrm{~h}$. The current change of $24 \mathrm{~h}$-incubated electrode was slightly higher. However, such a long incubation period was neither essential nor practical, when the whole assay time was considered. Therefore, $2 \mathrm{~h}$ of hybridization time was selected for all further experiments.

\subsection{Analytical performance of the biosensor}

Analytical performance of the electrochemical DNA biosensor applications for P1, P2 and P3 probes were evaluated by the amperometric analysis. The amplified electrochemical signal was achieved by adding $\mathrm{H}_{2} \mathrm{O}_{2}(2 \mathrm{mM})$ in an electrochemical cell con- 


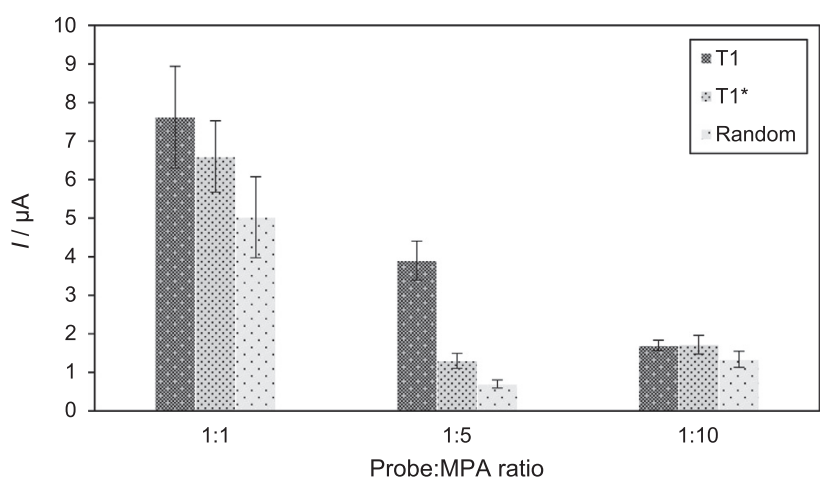

Fig. 1. Effect of Probe:MPA ratio on amperometric response of prepared biosensors (P2) for T1, T1*, and Random targets, respectively. Amprerometric responses were achieved after addition of $\mathrm{H}_{2} \mathrm{O}_{2}(2 \mathrm{mM})$ in $10 \mathrm{ml}$ of PBS $(0.1 \mathrm{M}, \mathrm{pH} 7.4)$ containing $1 \mathrm{mM}$ hydroquinone at applied potential of $-0.15 \mathrm{~V}$ ( $\mathrm{vs} . \mathrm{Ag} / \mathrm{AgCl})$.

taining $0.1 \mathrm{M}$ PBS ( $\mathrm{pH} 7.4$ ) and $1 \mathrm{mM}$ hydroquinone as a mediator for heterogeneous electron transfer of the St-HRP enzyme at an applied potential of $-0.15 \mathrm{~V}$ (vs. $\mathrm{Ag} / \mathrm{AgCl}$ ). Graphs in Fig. 4 represent the amperometric responses of P1, P2 and P3 probes after hybridization with $1 \mu \mathrm{M}$ complementary target (T1), single-base mismatch target $\left(\mathrm{T} 1^{*}\right)$ and, random sequence, respectively. The increase in biosensor responses of P1, P2 and P3 probes was observed after hybridization with their corresponding target DNA. However, a significant signal difference between P2/T1 and $\mathrm{P} 2 / \mathrm{T} 1$ * probe after hiybridizations with the complementary and the single-base mismatch was achieved. These results demonstrated the high selectivity of $\mathrm{P} 2$ probe, successfully discriminating the complementary target from single-base mismatch DNA. Table 3 shows the mean current changes of each probe after hybridization with $\mathrm{T} 1$ and $\mathrm{T} 1{ }^{*}$ in three repeated experiments. Maximum current changes were obtained when all probes (P1, P2 and P3) were hybridized with their perfect complementary targets. However, P1 had the most unstable results when relative standard deviation (RSD) values in Table 3 were evaluated.

Although P1 was designed to achieve $100 \%$ hybridization efficiency thermodinamically, it was not possible to perform a sufficiently stable biosensor application with it due to some mechanical and morphological incompatibilities to the experimental method. Distance between the electrode surface and biotin at $3^{\prime}$ end of the P1 probe was not short enough to prevent streptavidinHRP binding, which conveyed to nonreproducible results. This problem was overcome by designing another probe (P2), which

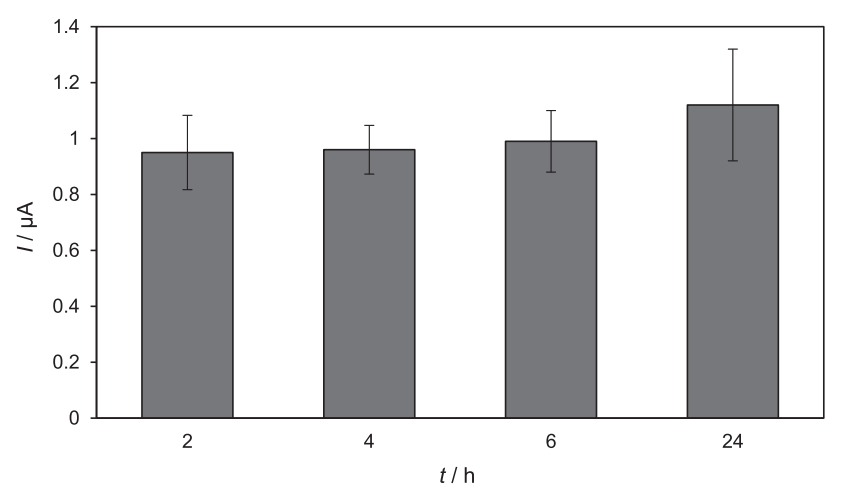

Fig. 3. Amperometric responses of biosensors for various hybridization periods after addition of $2 \mathrm{mM} \mathrm{H}_{2} \mathrm{O}_{2}$ in $10 \mathrm{ml}$ of PBS $(0.1 \mathrm{M}$, pH 7.4) containing $1 \mathrm{mM}$ hydroquinone at applied potential of $-0.15 \mathrm{~V}$.

was essentially a modification to P1 probe in order to make it compatible with the experimental method. In the design of P2 probe, C3 spacer at $5^{\prime}$ end was used instead of C6 spacer and the first nucleotide on $5^{\prime}$ end of P1 was omitted, two nucleotides were added to $3^{\prime}$ end. Consequently, RSD value for P2 probe was $15 \%$, which was not only a significant improvement from $30.9 \%$ calculated for P1 but also was comparable with previous studies [12,30-33]. The P3 probe was composed of a randomly selected sequence in a stable structure to demonstrate the feasibility of the method and was successfully applied in this study. Although P3/T3 hybrid had a higher thermodynamic affinity than P2/T1 hybrid, a significant signal increase was achieved with P2 probe. Probe length might affect the electrochemical signal since increasing the distance between enzyme and electrode surface might cause a decrease in electron transfer [34]. We should note that the length of P3 probe was 36 nucleotides long while P2 was only 22 nucleotides long.

In order to determine the maximum amperometric response that could be acquired for P2 modified biosensor, different concentrations of $\mathrm{T} 1(0.01$ to $0.4 \mu \mathrm{M})$ were applied. The results in Fig. 5 show that increase of current was proportional to concentration of target in the range from 0.01 to $0.2 \mu \mathrm{M}$. Amperometric response increased by increase in target DNA concentration and reached a maximum current of $3.22 \pm 0.49 \mu \mathrm{A}$ at the concentration of $0.2 \mu \mathrm{M}$. That point also represents the maximum hybridization efficiency for P2 modified biosensor, meaning the electrode surface was saturated to T1 target.
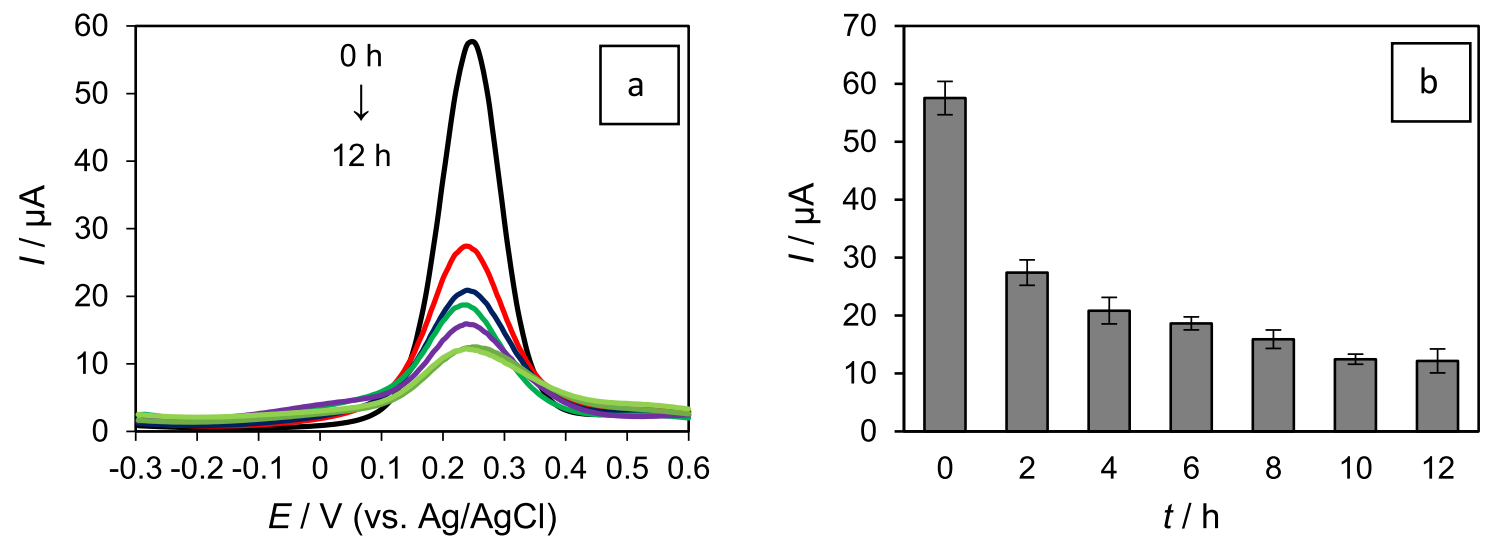

Fig. 2. SWVs (a) and acquired current values (b) for various incubation times (0-12 h) in $0.1 \mathrm{M} \mathrm{KCl}$ solution containing $5 \mathrm{mM}$ ferricyanide. 

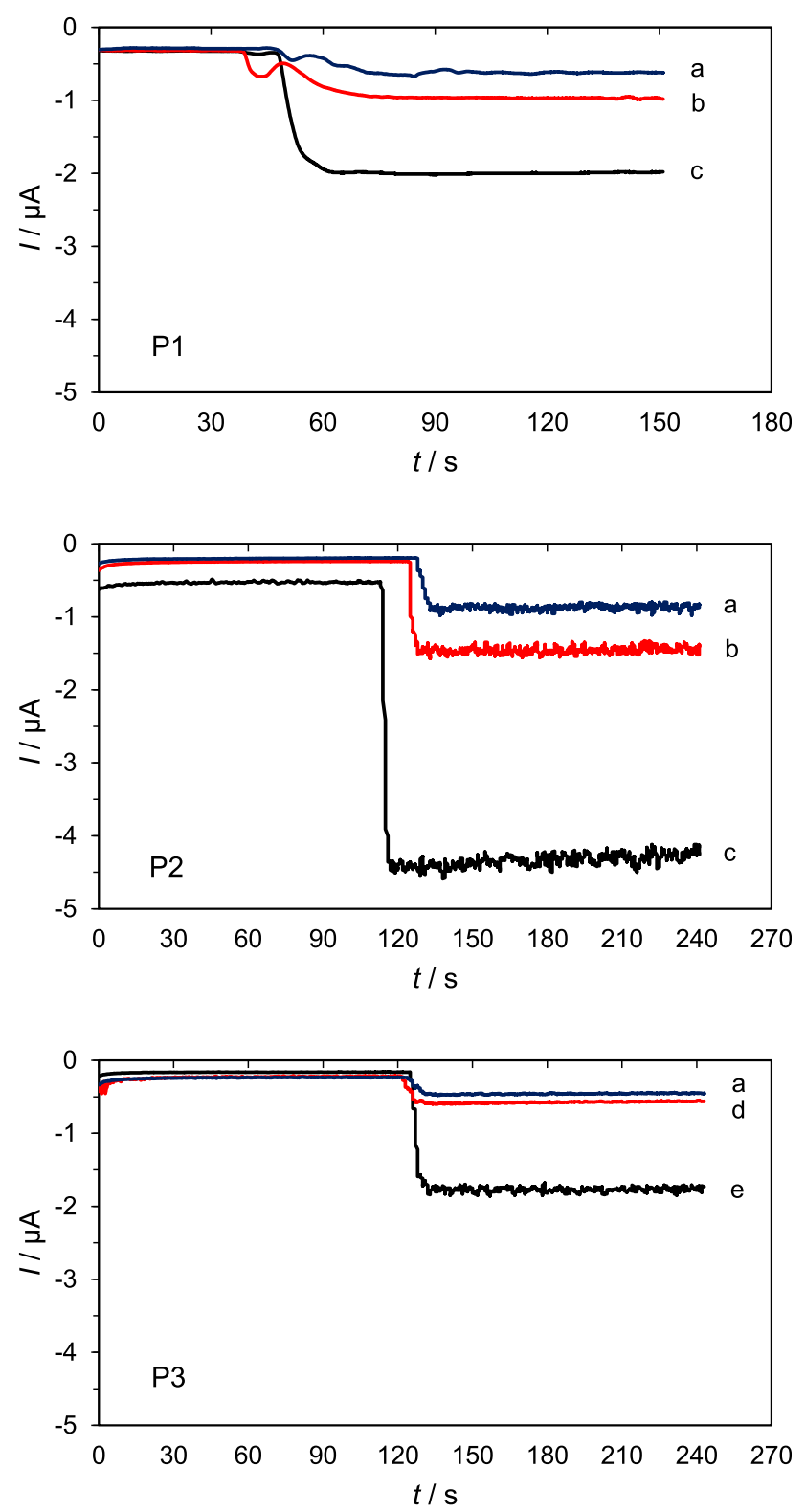

Fig. 4. Amperometric responses of the biosensors with $\mathrm{P} 1, \mathrm{P} 2$, and $\mathrm{P} 3$ after incubation with Random target (a), T1* (b), T1 (c), T3* (d), and T3 (e) after addition of $2 \mathrm{mM} \mathrm{H}_{2} \mathrm{O}_{2}$ in $10 \mathrm{ml}$ of PBS $(0.1 \mathrm{M}, \mathrm{pH} 7.4)$ containing $1 \mathrm{mM}$ hydroquinone at applied potential of $-0.15 \mathrm{~V}$.

Table 3

Comparison of probes used in experiments after hybridization with their complementary and single-base mismatch probes.

\begin{tabular}{lll}
\hline Hybridization Reactions & Current change $(\mu \mathrm{A})$ & RSD $(\%)$ \\
\hline $\mathrm{P} 1 / \mathrm{T} 1$ & $1.79 \pm 0.55$ & 30.9 \\
$\mathrm{P} 1 / \mathrm{T} 1^{*}$ & $0.66 \pm 0.28$ & 42.4 \\
$\mathrm{P} 2 / \mathrm{T} 1$ & $3.22 \pm 0.49$ & 15 \\
$\mathrm{P} 2 / \mathrm{T} 1^{*}$ & $0.58 \pm 0.08$ & 14.4 \\
$\mathrm{P} 3 / \mathrm{T} 3$ & $2.39 \pm 0.2$ & 8.6 \\
$\mathrm{P} 3 / \mathrm{T}^{*}$ & $0.29 \pm 0.03$ & 10 \\
\hline
\end{tabular}

\section{Conclusion}

This study has investigated the applicability of a thermodynamic approach in the design of target-specific DNA probes for use in electrochemical biosensors. Thermodynamic reactions in

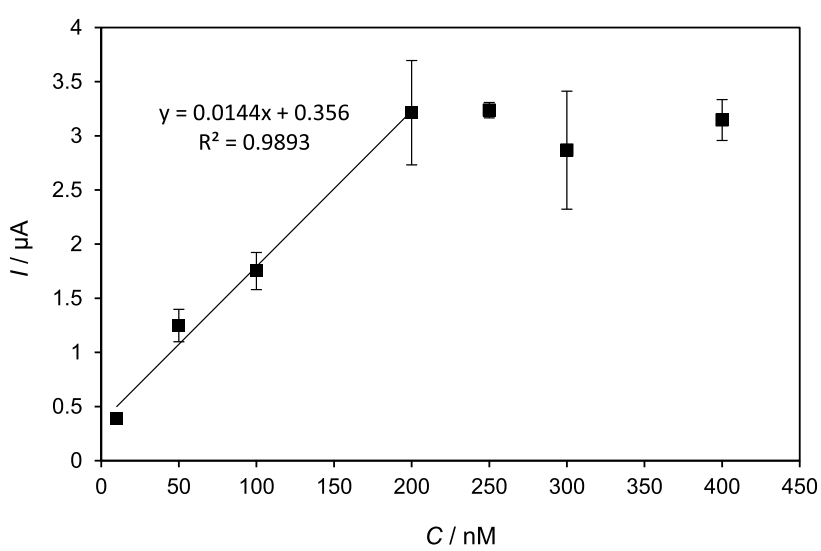

Fig. 5. Amperometric responses for the $\mathrm{P} 2$ probe hybridized with complementary target DNA at different concentrations $(10,50,100,200,250,300$ and $400 \mathrm{nM})$.

the design of an oligonucleotide probe were considered as a guiding frame, and hybridization conditions were investigated for stem-loop probes immobilized to a solid surface. Results showed successful applicability of probes designed with a thermodynamic model in electrochemical DNA biosensors. However, the findings revealed that this approach needs to be tailored to align with the experimental method. The present study provides an insight into the development of thermodynamic models for predicting the hybridization efficiency of DNA biosensors.

\section{Declaration of Competing Interest}

None.

\section{Acknowledgements}

This work was supported by TUBITAK, The Scientific and Technological Research Council of Turkey [grant number 110T664).

\section{Appendix A. Supplementary material}

Supplementary data to this article can be found online at https://doi.org/10.1016/j.bioelechem.2020.107553.

\section{References}

[1] S. Cagnin, M. Caraballo, C. Guiducci, P. Martini, M. Ross, M. Santaana, D. Danley T. West, G. Lanfranchi, Overview of electrochemical DNA biosensors: new approaches to detect the expression of life, Sensors 9 (2009) 3122-3148, https://doi.org/10.3390/s90403122.

[2] B.P. Nelson, T.E. Grimsrud, M.R. Liles, R.M. Goodman, R.M. Corn, Surface plasmon resonance imaging measurements of DNA and RNA hybridization adsorption onto DNA microarrays, Anal. Chem. 73 (2001) 1-7, https://doi.org/ 10.1021/ac0010431.

[3] C. Peter, M. Meusel, F. Grawe, A. Katerkamp, K. Cammann, T. Börchers, Optical DNA-sensor chip for real-time detection of hybridization events, Anal. Bioanal. Chem. 371 (2001) 120-127, https://doi.org/10.1007/s002160101006.

[4] J. Schotter, P.B. Kamp, A. Becker, A. Pühler, G. Reiss, H. Brückl, Comparison of a prototype magnetoresistive biosensor to standard fluorescent DNA detection, Biosens. Bioelectron. 19 (2004) 1149-1156, https://doi.org/10.1016/j. bios.2003.11.007.

[5] S. Storri, T. Santoni, M. Mascini, A piezoelectric biosensor for DNA hybridisation detection, Anal. Lett. 31 (1998) 1795-1808, https://doi.org/ $10.1080 / 00032719808005263$.

[6] C.E. Kirimli, W.Y.W.H. Shih, W.Y.W.H. Shih, DNA hybridization detection with 100 zM sensitivity using piezoelectric plate sensors with an improved noisereduction algorithm, Analyst 139 (2014) 2754-2763, https://doi.org/10.1039/ c4an00215f.

[7] T. Kaewphinit, S. Santiwatanakul, C. Promptmas, K. Chansiri, Detection of nonamplified Mycobacterium tuberculosis genomic DNA using piezoelectric DNAbased biosensors, Sensors 10 (2010) 1846-1858, https://doi.org/10.3390/ s100301846. 
[8] B. Meric, K. Kerman, D. Ozkan, P. Kara, M. Ozsoz, Indicator-free electrochemical DNA biosensor based on adenine and guanine signals, Electroanalysis 14 (2002) 1245-1250, https://doi.org/10.1002/1521-4109(200210)14:18<1245:: AID-ELAN1245>3.0.CO;2-V.

[9] G. Marrazza, I. Chianella, M. Mascini, Disposable DNA electrochemical biosensors for environmental monitoring, Biosens. Bioelectron. 14 (1999) 43-51, https://doi.org/10.1016/S0003-2670(99)00051-3.

[10] A. Shi, J. Wang, X. Han, X. Fang, Y. Zhang, A sensitive electrochemical DNA biosensor based on gold nanomaterial and graphene amplified signal, Sens. Actuat., B Chem. 200 (2014) 206-212, https://doi.org/10.1016/j. snb.2014.04.024.

[11] T. Hianik, V. Gajdos, R. Krivanek, T. Oretskaya, V. Metelev, E. Volkov, P. Vadgama, Amperometric detection of DNA hybridization on a gold surface depends on the orientation of oligonucleotide chains, Bioelectrochemistry 53 (2001) 199-204 (accessed May 30, 2019) http://www.ncbi.nlm.nih.gov/ pubmed/11339308.

[12] J. Hajdukiewicz, S. Boland, P. Kavanagh, A. Nowicka, Z. Stojek, D. Leech, Enzyme-amplified amperometric detection of DNA using redox mediating films on gold microelectrodes, Electroanalysis 21 (2009) 342-350, https://doi. org/10.1002/elan.200804395.

[13] A. Liu, K. Wang, S. Weng, Y. Lei, L. Lin, W. Chen, X. Lin, Y. Chen, Development of electrochemical DNA biosensors, TrAC - Trends Anal. Chem. 37 (2012) 101111, https://doi.org/10.1016/j.trac.2012.03.008.

[14] E. Paleček, Oscillographic polarography of highly polymerized Deoxyribonucleic acid, Nature 188 (1960) 656-657, https://doi.org/10.1038 $188656 a 0$.

[15] T.G. Drummond, M.G. Hill, J.K. Barton, Electrochemical DNA sensors, Nat. Biotechnol. 21 (2003) 1192-1199, https://doi.org/10.1038/nbt873.

[16] L.S. Yilmaz, L.I. Bergsven, D.R. Noguera, Systematic evaluation of single mismatch stability predictors for fluorescence in situ hybridization, Environ. Microbiol. $10 \quad$ (2008) 2872-2885, https://doi.org/10.1111/j.14622920.2008.01719.x.

[17] L.S. Yilmaz, D.R. Noguera, Development of thermodynamic models for simulating probe dissociation profiles in fluorescence in situ hybridization, Biotechnol. Bioeng. 96 (2007) 349-363, https://doi.org/10.1002/bit.21114.

[18] J. SantaLucia, A unified view of polymer, dumbbell, and oligonucleotide DNA nearest-neighbor thermodynamics, Proc. Natl. Acad. Sci. USA 95 (1998) 14601465, https://doi.org/10.1073/pnas.95.4.1460.

[19] J. SantaLucia, H.T. Allawi, P.A. Seneviratne, Improved nearest-neighbor parameters for predicting DNA duplex stability, Biochemistry. 35 (1996) 3555-3562, https://doi.org/10.1021/bi951907q.

[20] L.S. Yilmaz, D.R. Noguera, Mechanistic approach to the problem of hybridization efficiency in fluorescent in situ hybridization, Appl. Environ. Microbiol. 70 (2004) 7126-7139, https://doi.org/10.1128/AEM.70.12.71267139.2004.

[21] L.S. Yilmaz, H.E. Okten, D.R. Noguera, Making all parts of the 16S rRNA of Escherichia coli accessible in situ to single DNA oligonucleotides, Appl Environ. Microbiol. 72 (2006) 733-744, https://doi.org/10.1128/ AEM.72.1.733-744.2006.
[22] X. Mao, J. Jiang, X. Xu, X. Chu, Y. Luo, G. Shen, R. Yu, Enzymatic amplification detection of DNA based on "molecular beacon" biosensors, Biosens. Bioelectron. 23 (2008) 1555-1561, https://doi.org/10.1016/j.bios.2008.01.019.

[23] N. Sugimoto, S. ichi Nakano, M. Katoh, A. Matsumura, H. Nakamuta, T. Ohmichi, M. Yoneyama, M. Sasaki, Thermodynamic Parameters To Predict Stability of RNA/DNA Hybrid Duplexes, Biochemistry. 34 (1995) 11211-11216. doi:10.1021/bi00035a029.

[24] M. Zuker, Mfold web server for nucleic acid folding and hybridization prediction, Nucl. Acids Res. 31 (2003) 3406-3415. http://www. pubmedcentral.nih.gov/articlerender.fcgi?artid=PMC169194.

[25] H.E. Okten, L.S. Yilmaz, D.R. Noguera, Exploring the in situ accessibility of small subunit ribosomal RNA of members of the domains Bacteria and Eukarya to oligonucleotide probes, Syst. Appl. Microbiol. 35 (2012) 485-495, https://doi. org/10.1016/j.syapm.2011.11.001.

[26] W. Gao, H. Dong, J. Lei, H. Ji, H. Ju, Signal amplification of streptavidinhorseradish peroxidase functionalized carbon nanotubes for amperometric detection of attomolar DNA, Chem. Commun. 47 (2011) 5220-5222, https:// doi.org/10.1039/c1cc10840a.

[27] C. Liu, G.M. Zeng, L. Tang, Y. Zhang, Y.P. Li, Y.Y. Liu, Z. Li, M.S. Wu, J. Luo, Electrochemical detection of Pseudomonas aeruginosa 16S rRNA using a biosensor based on immobilized stem-loop structured probe, Enzyme Microb. Technol. 49 (2011) 266-271, https://doi.org/10.1016/j.enzmictec.2011.06.011.

[28] G. Liu, Y. Wan, V. Gau, J. Zhang, L. Wang, S. Song, C. Fan, An enzyme-based EDNA sensor for sequence-specific detection of femtomolar DNA targets, J. Am. Chem. Soc. 130 (2008) 6820-6825, https://doi.org/10.1021/ja800554t.

[29] C. Fan, K.W. Plaxco, A.J. Heeger, Electrochemical interrogation of conformational changes as a reagentless method for the sequence-specific detection of DNA, Proc. Natl. Acad. Sci. 100 (2003) 9134-9137, https://doi.org/ 10.1073/pnas.1633515100.

[30] L.E. Ahangar, M.A. Mehrgardi, Amplified detection of hepatitis B virus using an electrochemical DNA biosensor on a nanoporous gold platform, Bioelectrochemistry. 117 (2017) 83-88, https://doi.org/10.1016/j. bioelechem.2017.06.006.

[31] M. Ligaj, M. Tichoniuk, D. Gwiazdowska, M. Filipiak, Electrochemical DNA biosensor for the detection of pathogenic bacteria Aeromonas hydrophila, Electrochim. Acta. 128 (2014) 67-74, https://doi.org/10.1016/ j.electacta.2013.10.061.

[32] J. Orozco, L.K. Medlin, Electrochemical performance of a DNA-based sensor device for detecting toxic algae, Sens. Actuat., B Chem. 153 (2011) 71-77, https://doi.org/10.1016/j.snb.2010.10.016.

[33] A. Toldrà, C. Alcaraz, J. Diogène, C.K. O’Sullivan, M. Campàs, Detection of Ostreopsis cf. ovata in environmental samples using an electrochemical DNAbased biosensor, Sci. Total Environ. 689 (2019) 655-661, https://doi.org/ 10.1016/j.scitotenv.2019.06.448.

[34] L. Kékedy-Nagy, S. Shipovskov, E.E. Ferapontova, Effect of a dual charge on the DNA-conjugated redox probe on DNA sensing by short hairpin beacons tethered to gold electrodes, Anal. Chem. 88 (2016) 7984-7990. doi:10.1021/ acs.analchem.6b01020. 